\title{
China's Forensic Science Reform: Progress and Prospects
}

\author{
Jiang $\mathrm{Na}$ \\ College for Criminal Law Science, Beijing Normal University, Beijing, China \\ Email: na.jiang@bnu.edu.cn
}

Received 21 April 2014; revised 26 May 2014; accepted 12 July 2014

Academic Editor: Pingxue Zou, School of Law, Shenzhen University, China

Copyright (C) 2014 by author and Scientific Research Publishing Inc.

This work is licensed under the Creative Commons Attribution International License (CC BY).

http://creativecommons.org/licenses/by/4.0/

(c) (i) Open Access

\section{Abstract}

China's forensic reform in $\mathbf{2 0 0 5}$ has made positive progress on the forensic system in many aspects. Apart from abolishing forensic sectors in courts, increasing such sectors funded by social bodies and improving the quality of forensic examination, there has been significant progress on infrastructure and equipment construction in practice. With investments from Party committees or governments, forensic agencies including those inside police and supported by social sectors have achieved desirable results in developing their capacity building in recent years. Nonetheless, the independence of forensic sectors that the 2005 reform did attempt to improve appears not to change much the situation of investigative bodies conducting forensic examination. In fact, the police control forensic work after investigation so as not to ensure impartiality of forensic results made by police forensic experts. Thus, China need to create independent scientific institutions for forensic research, analyses and free casework in future reform, in order to build support for an overhaul of forensic science. Regardless in a broad or narrow sense, meanwhile, the "independent" nature of forensic institutes never requires abolition of those inside police. But their independence from the three institutions including police is still at the core of further forensic science reform in China.

\section{Keywords}

Forensic Science, Latest Reform, Positive Progress, Future Prospects

\section{Introduction}

In order to build support for an overhaul of China's forensic science, the centerpiece of the government's reform 
strategy is to create a series of independent scientific institutions that provide forensic analyses for police, prosecutors and defense lawyers alike. The reformists face a tough task, however, in convincing colleagues how independent forensic institutes should be, the importance of abolishing police forensic sectors, like crime scene investigation units, and how to remedy the failing system of forensic science. Both progress and prospects will be examined to assess the reform.

\section{Achievements and Progress}

Based on a narrow sense of independence, China's forensic reform retains police forensic agencies while developing social sectors, and has achieved some progress on the capacity building of forensic agencies, particularly those inside police. Over the past years, the Ministry of Public Security has implemented a range of effective measures to further standardization and modernization of forensic appraisal (China News, 2006), as well as building the capacity of forensic agencies inside police where investigators do not work well. In such police agencies, forensic experts often conduct judicial identification to provide with reliable witnesses, and the above measures help them produce more accurate forensic appraisals in court, even though not all judges subsequently admit them as forensic evidence. By increasing investment, improved certification and accreditation systems, and introducing new "key institutions", the number of forensic experts has expanded to form a nationwide net of forensic investigation (Legal Info, 2012), for the efficiency of forensic identification and the quality of appraisal results (Xu Jinghe, 2012).

There has also been significant progress on infrastructure and equipment construction, with huge investments from the Party committees and governments at all levels. Currently, 4850 forensic sectors have registered in China, (Legal Info, 2013) including 10 national key judicial authentication ones with top ranking of experts and resources, (Legal Info, 2014) many core ones funded by and affiliated to the police system and key judicial identification laboratories researching particular areas. China had set up 258 DNA laboratories with overall advanced functions, equipped with 558 DNA sequencing instruments and 94 automatic workstations (Wang Chuanzong, 2011). These laboratories can analyze 1.2 million samples every year (Chen Dongsheng, 2012). Moreover, the government has invested hundreds of billions of RMB in forensic equipments in urban areas, like those involving the Shanghai building for criminal technology, at the international first-class scale and level. Another case is in 2009 alone when the central and local authorities transferred to local police, (Chen Dongsheng, 2012) the total payments of 19.8 billion renminbi (RMB) (ca. US\$ 2.8 billion, half from the central), which was emphasized to use only for the technical equipments of forensic agencies inside police.

Furthermore, the Ministry of Public Security has implemented a national accreditation system for forensic laboratories and identification agencies. This system promotes the transformation and improvement of forensic institutions at all levels of governments, according to uniform standards. In the tests of forensic proficiency organized by the Ministry of Justice, the comprehensive results of the accreditation bodies in all provinces are increasing. For example, in 2011, 97\% of all projects passed examinations in Zhejiang Province (Chen Dongsheng, 2012). The number of projects where forensic bodies in this province have been deemed to be "satisfactory" is about $81 \%$ among projects under testing, much higher than the percentage points that around $51 \%$ of national projects are deemed "satisfying” (Chen Dongsheng, 2012).

Another progress indicator is the implementation of the regulatory responsibility that judicial administrative bodies at all levels of governments examine and supervise all forensic bodies, in order to ensure the standardized development of forensic industry. In practice, China has organized annual inspections and checks of accreditation bodies, deployed special examinations on forensic clinical identification and strictly dealt with any identified problems. Responding to the sharp increase of forensic complaints, the Ministry of Justice's Approaches to Handling Complaints in Forensic Practice has been conscientiously implemented to regulate complaints and strengthen supervision of forensic identification (Zhou Bin, 2010). Hence, the number of forensic complaints began to decrease from 2011, 70.5\% lower than that in 2009, since 1 June 2010 when the forensic complain system was first introduced (Zhu Chunliang et al., 2011). It suggests that recent progress and achievements enable forensic agencies handle more forensic work and improve the good quality of forensic evidence.

\section{Future Developing Trends}

To improve forensic science in China, more independent institutes must be established that "could carry out research and do casework free of charge, making the results available to [those on] both sides of a case" (Page, 
2003). The independence of forensic institutes does not necessarily require abolishing all of forensic sectors affiliated to the authorities, but in essence prevent any authorities responsible for investigation, prosecution or trail from conducting forensic identification as well in the same cases. It indicates the scope of their independence from authorities and the essence of abolishing forensic sectors affiliated to police. Accordingly, more social institutes should be greatly expanded so as to undertake most forensic work that police agencies currently do and such police agencies should take other forensic workload in cases investigated by non-police, in order to remedy the failing system of forensic science.

As demonstrated from above progress and challenges, China has invested a lot of money to improve the current situation and made remarkable achievements, but institutional problems on the function and task of police forensic sectors seem to be steadily deteriorating. This is at the core of the flawed 2005 reform, mainly on the basis of traditionally too much reliance placed on biased police investigators in conviction and of random prevention against impartial police agency experts' testifying by authorities given conflict of interests. Although the Criminal Procedure Law of the PRC effective 2013 excludes illegally obtained evidence and protects experts' testifying in court ${ }^{1}$, there is no much change on the fundamentally unjust system of self-investigation and selfidentification, given a high conviction rate (Boehler, 2013) and no guarantee of cross-examination in practice. Hence it is necessary for China to launch a new round of forensic reform, intended to open more social forensic agencies to the public for increasing forensic inconvenience, independence from and supervision over police investigators. This represents a promising break from the traditional practice that most forensic science activities are often decided or managed through investigative police without suspects' participation.

These institutes could be developed based on current forensic sectors outside non-police, such as those affiliated to universities, research institutions or hospitals, and qualified research sectors with forensic identification certificate granted by national judicial administrative bodies. The authorities should encourage rather than limit private funding for the development of forensic labs in achieving the goals of forensic science reform. Also, providing forensic sectors with a broader mandate is essential to better prevent the use of tainted forensic evidence and the subsequent wrongful convictions that such evidence can cause. At the very least, each independent sector "needs to be a multidisciplinary group to cover the whole criminal justice system", given the high risk of wrongful convictions in capital cases. Additionally, suspects should be able to initiate forensic examination as a matter of right, and these examinations should be administered separately from the investigations instigated by authorities. In essence, all of forensic organizations must develop a new culture whereby they serve justice, rather than the convenience of the authorities, promoting their experts to undertake independent and impartial forensic work.

\section{References}

Boehler, P. (2013). Supreme People’s Court Judge Urges End to Wrongful Convictions. South China Morning Post. http://www.scmp.com/news/china/article/1232279/supreme-peoples-court-judge-urges-end-wrongful-convictions

Chen Dongsheng 陈东升 (2012). Zhejiang sifa jianding nengli wunian quanguo kaoqian 浙江司法鉴定能力五年全国靠 前. Legal Daily. http://www.legaldaily.com.cn/bm/content/2012-04/21/content 3520150.htm

China News (2006). Zhongguo gong’an bu litui sifa jianding fazhi hua biaozhun hua he xiandai hua 中国公安部力推司法 鉴定法制化、标准化和现代化.

http://www.chinanews.com/news/2006/2006-01-19/8/680202.shtml

Legal Info (2012). Woguo sifa jianding tongyi guanli tizhi yijing xingcheng 我国司法鉴定统一管理体制已经形成. http://www.legalinfo.gov.cn/moj/zgsfjd/content/2012-11/23/content_4008067.htm

Legal Info (2013). Wunian banli liubai yishiwu wan sifa jianding an 5 年办理 615 万司法鉴定案. http://www.legalinfo.gov.cn/moj/zgsfjd/content/2013-01/10/content_4122076.htm

Legal Info (2014). Shijia guojia ji sifa jianding jigou jianjie 10 家国家级司法鉴定机构简介. http://www.legalinfo.gov.cn/index/content/2010-10/22/content_2324633.htm

Page, K. (2003). Reformers Aim to Shake up British System, Science, 301, 579-580. http://dx.doi.org/10.1126/science.301.5633.579a

${ }^{1}$ See "Criminal Procedure Law of the People's Republic of China" (amended for the second time in accordance with the Decision on Amending the Criminal Procedure Law of the People's Republic of China adopted at the 5th Session of the Eleventh National People's Congress on March 14, 2012). http://www.lawinfochina.com/display.aspx?lib=law\&id=9247\&CGid= 
Jiang N.

Wang Chuanzong 王传宗 (2011). Wanshan sifa jianding biaozhun guifan jianyan jianding gongzuo 完善司法鉴定标准 规范检验鉴定工作. China Police Net. http://www.cpd.com.cn/n336929/n1172899/n1172901/c1249507/content.html

Xu Jinghe 徐景和 (2005). Shenhua sifa jianding gaige shixian jige zhuanbian quebao sifa gongzheng 深化司法鉴定改革 实现几个转变 确保司法公正. Legal Info. http://www.legalinfo.gov.cn/moj/zgsfjd/2005-10/25/content_220040.htm

Zhou Bin 周斌 (2010). Sifa jianding zhiye huodong tousu chuli banfa fabu shishi 《司法鉴定执业活动投诉处理办法》发 布实施. Legal Daily. http://www.legaldaily.com.cn/bm/content/2010-04/09/content_2108050.htm

Zhu Chunliang 朱淳良 et al. (2011). Zhejiang sheng duocuo bingju zhuahao sifa jianding tousu chuli gongzuo 浙江省多措 并举抓好司法鉴定投诉处理工作. Zhongguo Sifa Jianding, 2, 93. 
Scientific Research Publishing (SCIRP) is one of the largest Open Access journal publishers. It is currently publishing more than 200 open access, online, peer-reviewed journals covering a wide range of academic disciplines. SCIRP serves the worldwide academic communities and contributes to the progress and application of science with its publication.

Other selected journals from SCIRP are listed as below. Submit your manuscript to us via either submit@scirp.org or Online Submission Portal.
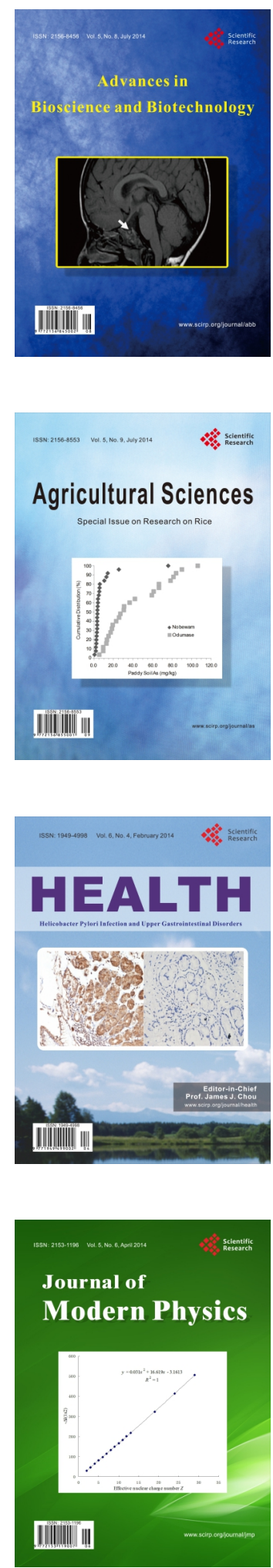
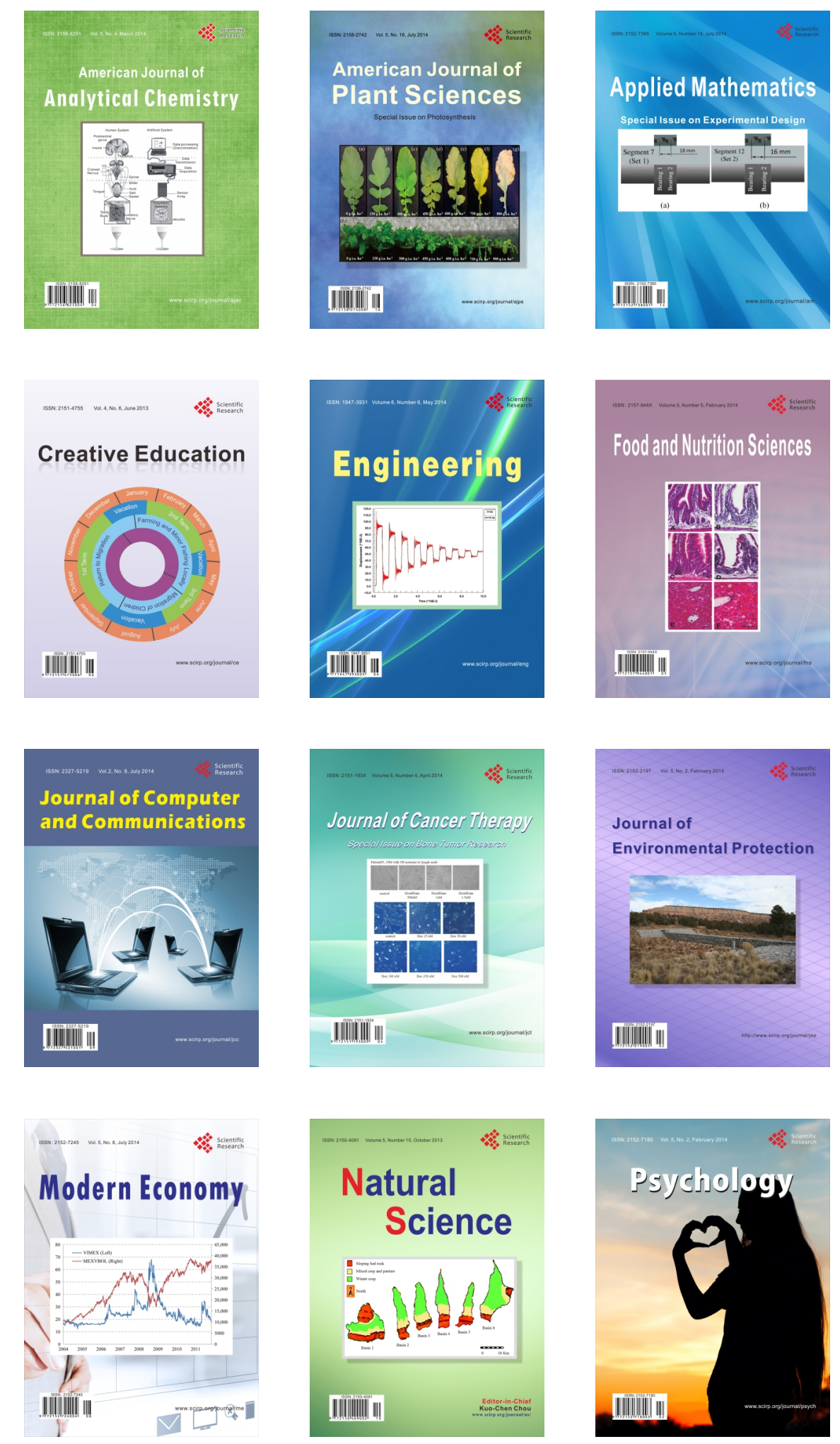